\title{
A SECA DE 1980-81 EM PORTUGAL CAUSAS METEOROLÓGICAS E TIPOS DE TEMPO
}

\section{ANTONIO DE BRUM FERREIRA} DENISE DE BRUM FERREIRA

As secas constituem um tema de innegável interesse geográfico. O seu estudo completo é, todavia, bastante complexo, pois, além da compreensăo das suas causas, do ponto de vista meteorológico, torna-se necessário definir a sua intensidade e extensão, o grau de ocorrência e consequências muito diversas, de que se destacam, pela sua importância, as implicações na agricultura e na reconstituição (melhor se diria no esgotamento) das reservas de água.

O presente trabalho( $\left.{ }^{1}\right)$ é uma achega para o estudo da seca ocorrida no ano hidrológico de 1980-81 e no começo do ano seguinte, incidindo fundamentalmente sobre as situações meteorológicas que a determinaram. Ainda é cedo para se fazer um balanço rigoroso das consequências económicas desta seca, uma das mais graves desde que há registos meteorológicos em Portugal. Para além de se reflectir numa quebra muito acentuada da produção de electricidade de origem hidráulica $\left({ }^{2}\right)$, ela fez-se sentir de modo particular na agricultura, cujas produções sofreram reduções muito

(1) Retoma-se e completa-se um trabalho anterior dos nutores, difundido sob forma policopiada, Alguns aspectos da seca invernal de 1980-81 em Portugal, Linha de Aç̧ão de Geografia Física, Rel. n. ${ }^{\circ}$ 13, CEG, Lisboa, $1981,46 \mathrm{p}$.

(2) Essa quebra foi geralmente superior a $50 \%$ nos meses de Janeiro a Junho de 1981, relativamente a iguais meses do ano anterior. Ver Boletim Mensal de Estatistica. INE, L.isboa, 1982, n. ${ }^{\circ} 4$. 
importantes, quer em relação ao ano anterior quer relativamente ùs médias do último decénio $\left({ }^{3}\right)$. Ora, os prejuízos causados na agricultura não resultaram apenas da falta de chuva e da diminuição ou esgotamento das reservas de água no solo; certas culturas, nomeadamente as de árvores de fruto (citrinos, oliveira, castanheiro), foram profundamente afectadas pelas geadas, que constituem um verdadeiro flagelo dos Invernos secos. Assim, para além da explicação da indigência das precipitações, tentar-se-á definir as condições atmosféricas que originam as vagas de ar frio favoráveis às verdadeiras geadas e às chamadas geadas negras.

A seca de 1980-81. foi, fundamentalmente, uma seca de Inverno, tendo atingido a sua fase mais grave em meados de Fevereiro. Depois de uma Primavera que se pode considerar próxima do normal, em termos de precipitação, seguiu-se um Verão particularmente quente e seco e um Outono de novo anormalmente pouco chuvoso. Pode dizer-se que a seca só findou com as chuvas excepcionalmente abundantes de Dezembro de 1981. Não vamos fazer uma monografia das situações atmosféricas de todo este período, aliás cheio de motivos de interesse, mas apenas tentar explicar a escassez de precipitação do Inverno de 1980-81 e do Outono de 1981, uma vez que a secura estival, embora particularmente marcada nesse ano, constitui uma característica essencial do clima de Portugal.

\section{A EVOLUÇÃO DA PRECIPITAÇAOO E DO BALANÇO HIDRICO DE OUTURRO DE 1980 A MARÇO DE 1981}

A PRECIPITAÇÃO. - Para o estudo da precipitação escolheram-se as seguintes estações meteorológicas: Viana do Castelo, Bragança, Coimbra, Penhas Douradas, Lisboa, Évora, Beja e Faro. Essa escolha obedeceu a dois critérios: por um lado, uma distribuj-

(3) A maior parte dos principais produtos agrícolas (cereais, batata, tomate, fruta, vinho, azeite) apresentou uma quebra de produção de 20 a $40 \%$ relativamente ao ano anterior e ao viltimo decénio, segundo clados provisórios do INE (ver Boletim Mensal das Estatísticas da Agricultura e da Pesca, 1981, n. 10,11 e 12 , e 1982 n. 1,2 e 3). Mais difícil de contabilizar é a diminuição da produção de alimentos verdes para o gado, quer se trate de culturas forrageiras quer de pastagens naturais, e que constituiu uma das consequências mais preocupantes da seca. cão que permitisse dar uma imagem do conjunto do país; por outro, a existência de séries bastante longas de registos e de dados recentes publicados, nomeadamente no boletim meterrológico diário e no boletim meteorológico para a agricultura. A duração das séries utilizadas não é, todavia, a mesma para as diferentes estações: 80 anos (1901-80) para Coimbra, Lisboa, Évora, Beja e Faro; 50 anos (1931-80) para Viana do Castelo, Bragança e Penhas Douradas.

Analisemos em primeiro lugar o total das precipitações registadas no semestre de Outubro a Março. A fig. 1 representa, para cada uma das estações meteorológicas consideradas, as precipitações ocorridas em 1980-81, assim como a mediana, o quintil inferior e o valor mínimo da série respectiva. Verifica-se que, salvo em Viana do Castelo, o total das precipitações ocorridas de Outubro a Março do ano hidrológico de $1980-81$ foi inferior ao quintil inferior. Em oitenta anos de observações, apenas se registaram valores mais baixos oito vezes em Faro, cinco em Lisboa, três em Coimbra, uma em Évora e nenhuma em Beja. Em cinquenta anos de observações, houve dois valores mais baixos em Bragança, em Penhas Douradas apenas um, enquanto em Viana do Castelo esse número se eleva para catorze, constituindo, assim, um caso à parte.

1. Por aqui se vê o carácter excepcional das precipitações outono-invernais do ano hidrológico de 1980-81. Mas nem todos os meses contribuíram de igual! modo para esses valores anormalmente baixos (fig. 2). Em Outubro e Novembro, as precipitações foram próximas do normal. Em Dezembro e Janeiro, elas foram geralmente inferiores no decil inferior. Quer dizer: precipitações tão baixas, em cada um desses meses, são de esperar apenas de dez em dez anos. Ora, no ano hidrológico de 1980-81, isso aconteceu em ambos os meses (com excepção de Viana do Castelo, em que a precipitaçăo de Dezembro foi superior ao decil inferior). Em oitenta anos de observações, as precipitações de Dezembro só foram mais baixas cinco vezes em Coimbra, uma em Lisboa, em Évora e em Beja, e nenhuma em Faro. Por sua vez, Janeiro foi um mês extremamente seco em todo o país. Segundo o boletim meteorológico para a agricultura, as precipitações foram nulas em Bragança choveu apenas $1 \mathrm{~mm}$ em Penhas Douradas, $2 \mathrm{~mm}$ em Coimbra, $3 \mathrm{~mm}$ em Évora, $4 \mathrm{~mm}$ em Beja e em Faro, $12 \mathrm{~mm}$ em Lisboa e $18 \mathrm{~mm}$ em Viana do Castelo. 


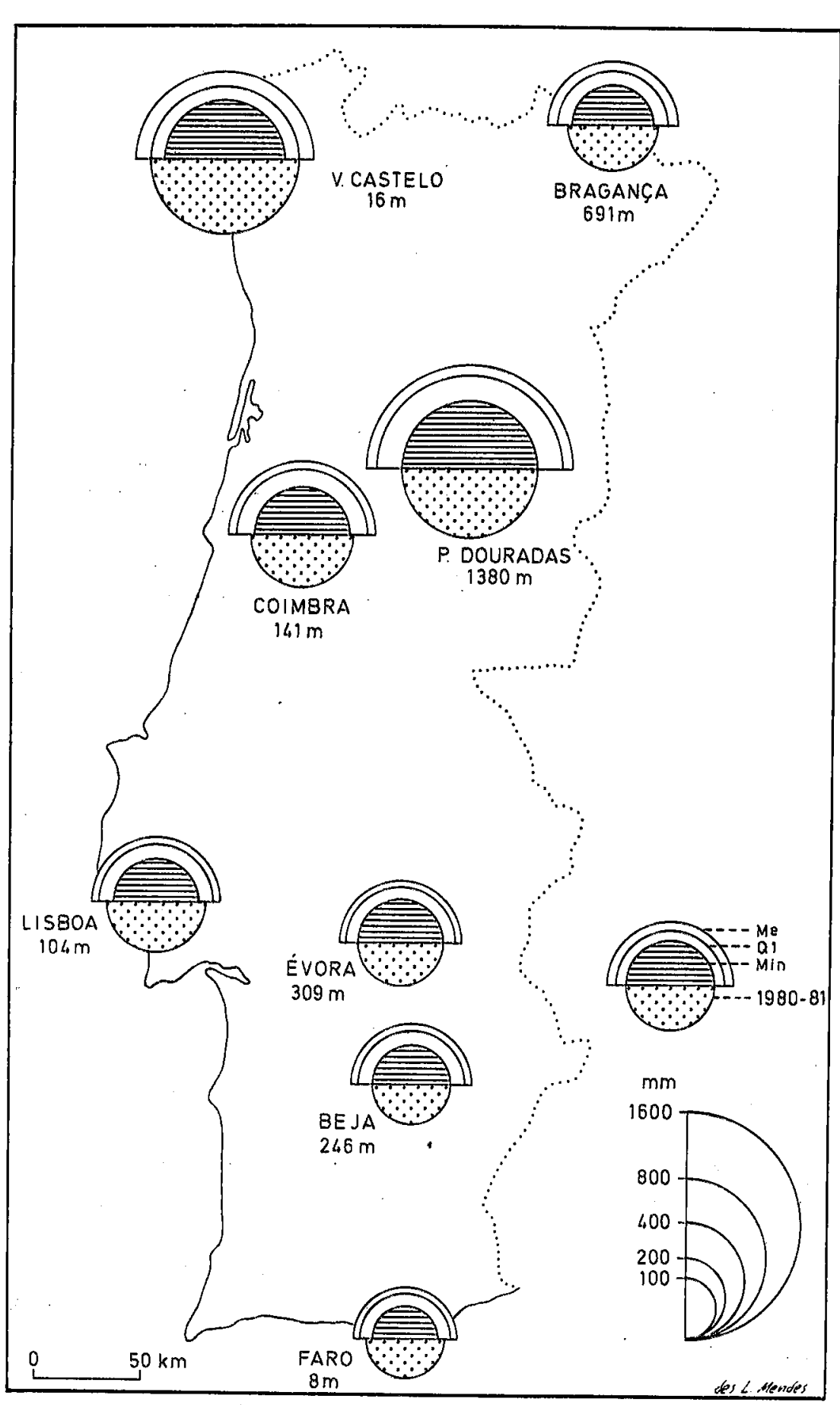

Fig. 1-Precipitaçóes ocorridas no semestre de Outubro a Março (totais). $\mathrm{Me}$-mediana; Q1 - quintil inferior; Min. - valor mínimo observado.
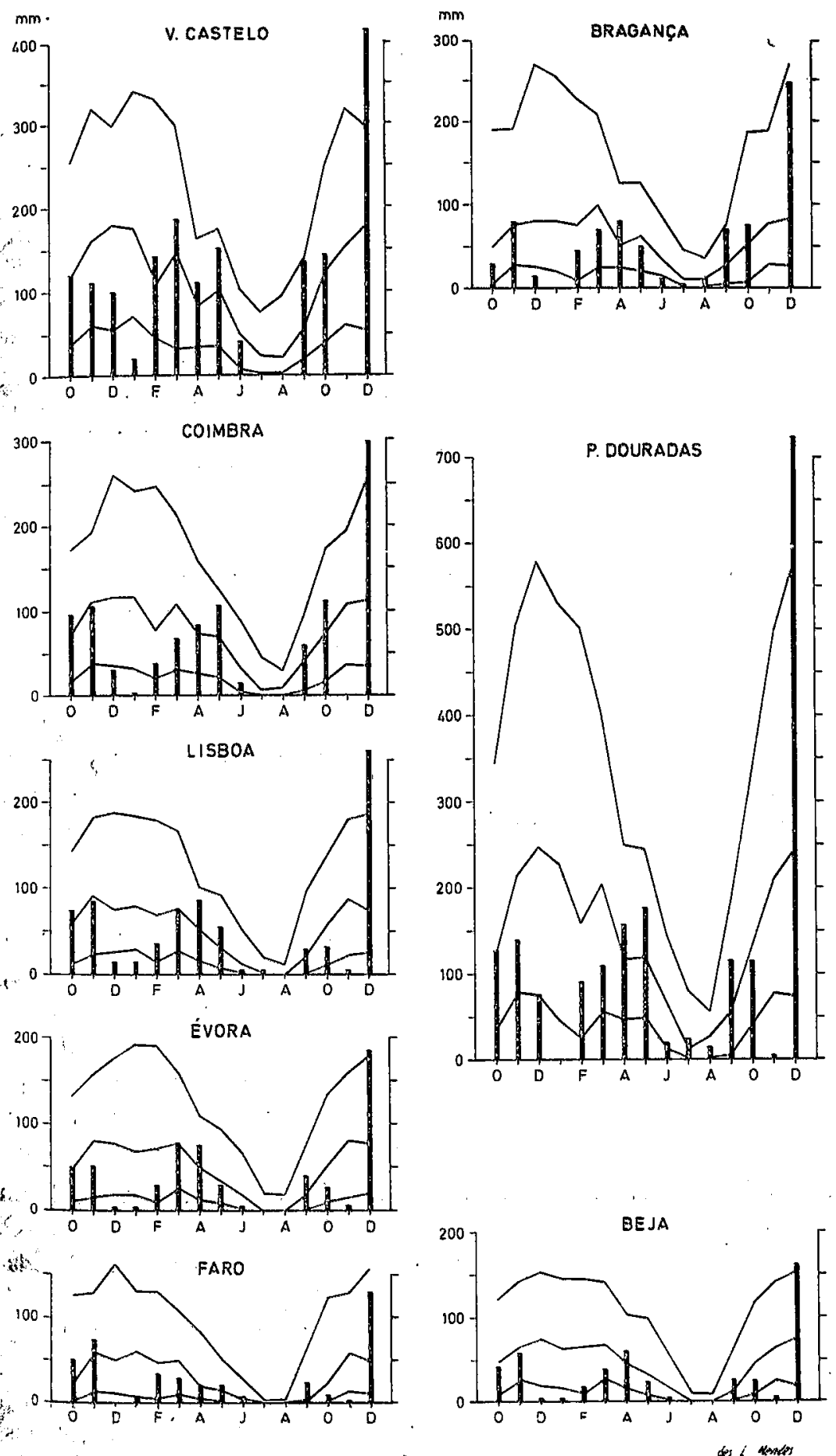

Fig. 2-Variaçầ mensal das precipitações. As curvas representam a mediana, o quintil inferior e o decil inferior; as barras referem-se às precipitações ocorridas de Outubro de 1980 a Dezembro de 1981. 
O mês de Fevereiro marca geralmente uma inflecção, no sentido de uma melhoria das condições, em termos de precipitação média mensal. Em Viana do Castelo, a precipitação de Fevereiro ultrapassou mesmo a mediana $\left({ }^{4}\right)$. Nas restantes estações, as altulras registadas são sempre superiores ao decil inferior, embora ainda fiquem muito aquém da mediana, particularmente em Beja, onde as precipitações desse mês foram inferiores ao quintil inferior. Março acentua, de modo geral, a tendência de Fevereiro. Todavia, nalgumas estações as chuvas de Março foram ainda escassas: em Faro e em Coimbra, os valores observados são inferiores ao segundo quintil e, em Beja, são iguais ao quintil inferior.

Mas a definição da seca, do ponto de vista pluviométrico, não pode ater-se apenas aos valores médios mensais ocorridos. O que constituiu, aliás, o aspecto mais grave e excepcional desse Inverno, do ponto de vista das chuvas, não foi apenas a ocorrência de meses extremamente secos, mas a circunstância de as precipitações terem sido praticamente nulas durante um período muito longo. Embora o mês de Novembro de 1980, no seu conjunto, se possa considerar normal ou próximo do normal, a verdade é que a terceira década desse mês registou já um défice pluviométrico muito acentuado. Assim, em Coimbra, Lisboa, Beja e Faro ocorreram precipitações entre 0,4 e $3,9 \mathrm{~mm}$, quando os valores normais desse período, nessas estações, se situam entre 20 e $30 \mathrm{~mm}$. Por outro lado, embora Fevereiro represente uma melhoria nas condições pluviométricas, depois dos meses excepcionalmente secos de Dezembro e Janeiro, as chuvas das cluas primeiras décadas foram ainda muito escassas $\mathrm{e}$ as da terceira década ocorreram fundamentalmente nos últimos três dias do mês. Contabiliza-se, assim, um período de três meses e meio em que as precipitações foram excessivamente baixas. Dois exemplos: segundo os elementos do boletim meteorológico diário, descle 14 de Novembro até 25 de Fevereiro caíram apenas $16,4 \mathrm{~mm}$ em Bragança e $10,4 \mathrm{~mm}$ em Beja, quando é de esperar, no mesmo período, cerca de $400 \mathrm{~mm}$ em Bragança e $250 \mathrm{~mm}$, aproximadamente, em Beja. Em Bragança, a precipitação manteve-se praticamente nula ( $1,0 \mathrm{~mm}$ no total.) entre 22 de Dezembro e 21 de Fe-

(4) Ultrapassou a mediana, mas não a média. É de notar, aliás, que em todas as estaçôes estudadas a mediana é inferior à média; por outras palavras, as precipitações mensais inferiores à média têm maior probabilidade cle ocorrência do que as precipitações supariores à média. vereiro; em Beja, a precipitação foi mesmo nula entre 22 de Dezembro e 30 de Janeiro.

O BALANÇO HÍdRICO. - Até aqui falámos apenas em termos de precipitação. Ora, do ponto de vista agrícola e hidrológico, é fundamental, na definição da seca, ter-se em conta também a evapotranspiração e a reserva de água no solo.

$\mathrm{Na}$ fig. 3 representa-se $\left({ }^{5}\right)$, para uma dezena de estações que abrangem as mais diversas regiões do país, duas variáveis: $a$ ) a razão $P / P N$, expressa em percentagem, entre a precipitação acumulada e a precipitação acumulada normali, a partir de 1 de Setembro de $1980 ; b)$ a diferença $\mathrm{R}-\mathrm{RN}$, entre a reserva útil do solo e a reserva normal. Estes valores referem-se à situaçăo verificada de dez em dez dias $(10,20,30 / 31$ de cada mês; 10,19 e 28 , no caso de Fevereiro), desde 10 de Outubro de 1980 até 31 de Dezembro de 1981.

Se atendermos em primeiro lugar à relação $P / P N$, verifica-se, como seria de esperar, que as precipitações acumuladas no ano hidrológico de 1980-81 são claramente inferiores às precipitações acumuladas normais, havendo, todavia, diferenças acentuadas no espaço e no tempo. Em quase todas as estações, as precipitações acumuladas aproximam-se ou ultrapassam mesmo as precipitações acumuladas normais até final de Novembro de 1980. A principal excepção a esta regra é representada pela estação de Bragança, em que os valores de $\mathrm{P} / \mathrm{PN}$ são quase sempre inferiores a $50 \%$. A partir do final de Novembro é geral a descida dos valores $P / P N$ : em Janeiro, Fevereiro e Março eles situam-se abaixo de $50 \%$ em Bragança, Vila Real, Penhas Douradas, Lisboa, Evora e Beja; em Viana do Castelo, Porto, Coimbra e Faro, os valores de $P$ são sensivelmente iguais ou ligeiramente superiores a metade de PN.

No que se refere às diferenças R-R.N, os valores são positivos ou ligeiramente negativos até final de Novembro de 1980, tornando-se geralmente negativos nos meses seguintes. Os desvios em

(5) Com base em dados do INMG, relativos ao balanço hídrico diário. O cálculo da evapotranspiração potencial (ETP) é feito a partir da temperatura, segundo o método de Thornthwaite; a reserva de água útil no solo $\dot{e}$ fixada, convencionalmente, em $100 \mathrm{~mm}$; considera-se que, nos casos em que ETP for superior a $P$, a evaporação faz-se, sem limitações, em detrimento da reserva de água do solo. Trata-se, evidentemente, de simplificações arbiirárias, mas que permitem, apesar de tudo, uma mais segura percepção da realidade do que a simples consideração das precipitações. 


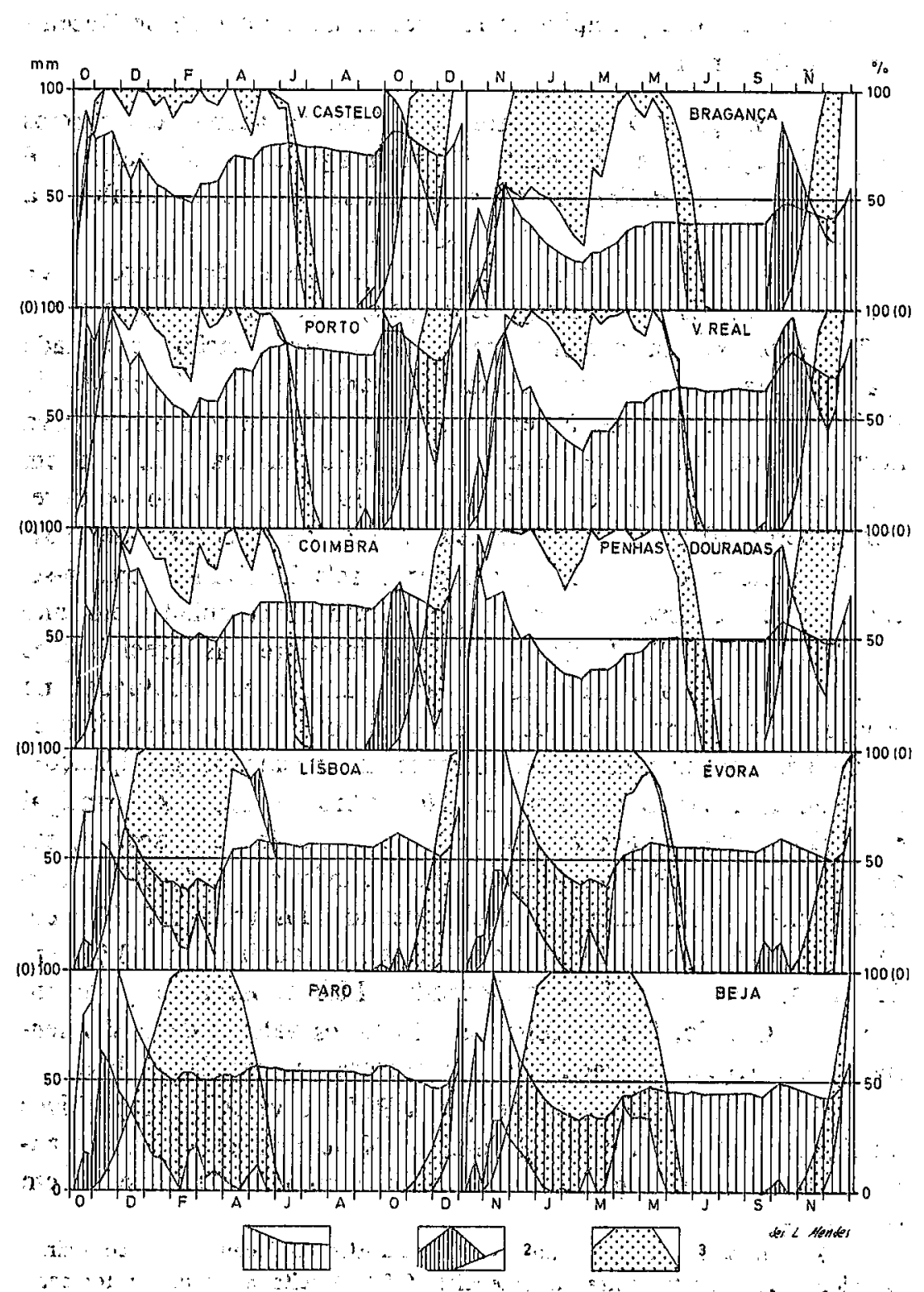

Fig. 3 -Precipitą̧óes e reservas de água no solo. 1 - relação $P / \mathrm{PN}$, expressa em: percentagem, entre a precipitação acumúlada em,1980-81: e a precipitação acumulada normal (não foram representados. os valores superior̨̧ a $100 \%$ ); 2-- diførença $R-R N$, expressa em mm, entre a reserva títil no solo en 1980-81 $\rightarrow$ a reserva normal, valores positivos; 3 -idem, valores negativos., relaçăo aos valores normais são particularmente elevados em Beja, Évora, Faro, Lisboa e Bragança, por ordem decrescente de intensidade Em Beja, a partir da primeira década de Janeiro, os valores de águà no solo variaram entre 0 e $20 \mathrm{~mm}$, numa altura do ano em que o solo costuma estar plenamente abastecido. Em Évora a situação foi semelhante, com esgotamento da reserva de água no solo entre meados de Janeiro e meados de Feverejro. Em Faro a situação foi também grave: em 10 de Fevereiro não havia água utilizável no solo quando, em ano normal, a reserva corresponde ao máximo teórico de $100 \mathrm{~mm}$. Em Lisboa a situação năo foi tão preo; cupante, mas a reserva de água no solo esteve à beira de esgotamento, oscilando de 26 a $6 \mathrm{~mm}$, entre a primeira década de Janeiro è a segunda década de $\operatorname{Março(}\left(^{\circ}\right)$.

Nitidamente menos desfavorável foi a situação das estações do Centro e do Norte do país, onde as reservas de água no solo nunca estiveram em risco de esgotamento, mesmo em Bragança, pelo menós a partir do princípio de Novembro de 1980. Esta última verificaçăo mostra o interesse de associar as reservas de água no solo na defininição da seca, quer do ponto de vista agrícola, quer do ponto de vista hidrológico. Nesse sentido é bein eluciclativa a comparação entre Bragança e Évora, por exemplo. Se atendermos apenas aos valores de P/PN, Évora parece nitidamente favorecida em relação a Bragança. Com efeito, os válores de $\mathrm{P} / \mathrm{PN}$ foram, em Évora, superiores a $100 \%$ até meados de Novembro, tornando-se ligeiramente inferiores a $50 \%$, apenas a partir do final de Janeiro. Em Bragança, pelo contrário, a razão $\mathrm{P} / \mathrm{PN}$ foi sempre inferior a $50 \%$, com excepção do mês de Novembro, e atingiu valores muito baixos, da ordem de $25 \%$, a partir de meados de Janeiro. Todavia, no que respeita às reservas de água no solo, enquanto as diferenças R-RN atingiram em Évora $-100 \mathrm{~mm}$, o que corresponde, teoricamente, ao esgotamento de água utilizável numa altura do anó em que o solo se encontra, hormalmente, abastecido, em Bragança, a partir do final de Novembro, esses valores nunca foram excessivamente baixos, atingindo um mínimo na segunda década de $\mathrm{Fe}$ vereiro, da ordem de $-70 \mathrm{~mm}$. Este resulltado deve-se não só " ao facto de as precipitações, a partir de meados de Novembro, 


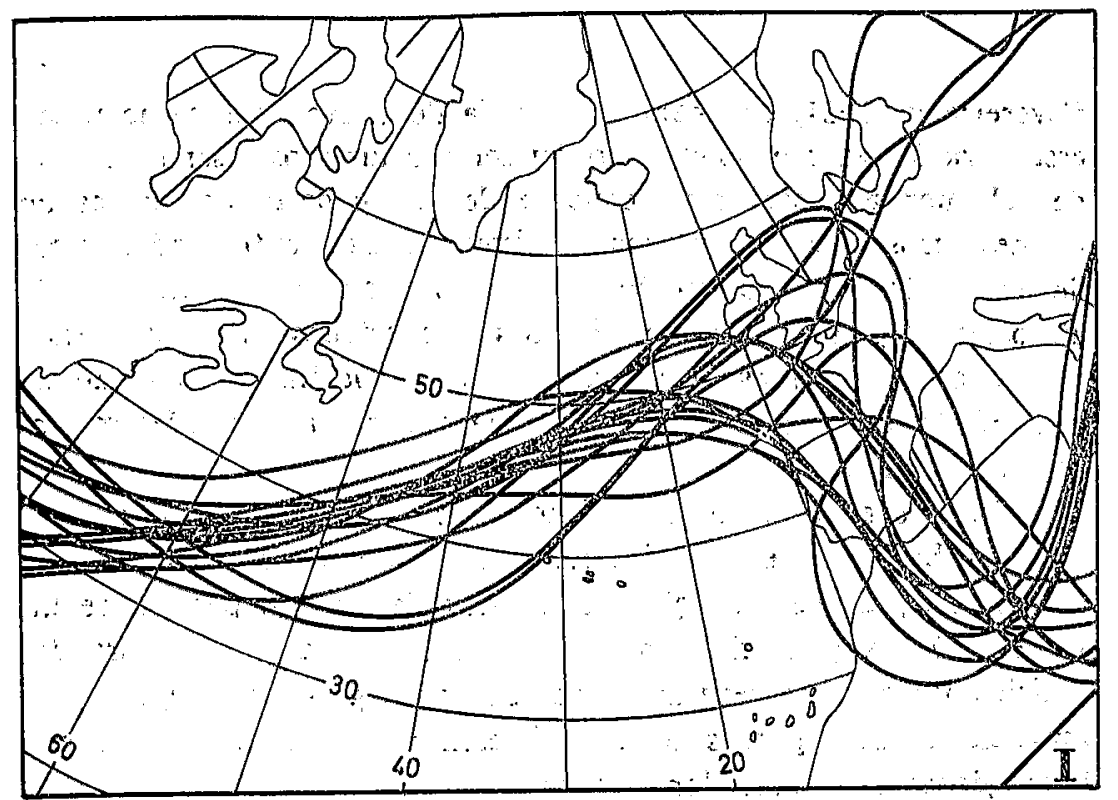

ondulações da corrente de oeste desvaneceu as perspectivas de um ano relativamente húmido. $O$ bloqueio difluente do Atlântico orierıtal desapareceu, enquanto o jet, mais rápido, passou a descrever uma ondulação de grande comprimento de onda, originando um vale na metade ocidental do Atlântico e uma dorsa! do lado oriental (fig. 5-J). Assim, o jet polar, de direcção WSW-ENE no meio do Atlântico, é rejeitado para norte, deixando em posição de abrigo a Península Ibérica. Esta circulação alternou com outra mais francamente meridiana, dando origem a uma dorsal ainda mais pronunciada, que estende a sua influência até à Europa Ocidental (fig. 5-II). A jusante desta dorsal, que atingiu por vezes a Escandinávia, formam-se vales, também de grande amplitude, que atravessam o Mediterrâneo e atingem frequentes vezes a Argélia e a Tunísia. Enquanto em Portugal e na Espanha reinava uma situação de abrigo aerológico, a Itália, a Grécia e o Magrebe conheciam uma importante activiclade ciclónica.

Eim Fevereiro, a circulação meridiana foi de tal modo complexa que sse torna difícil representar, de maneira sintética, as trajectórias da corrente de oeste. Verifica-se, antes, a justaposiçăo de correntes que evoluem cada uma com a sua própria velociclade. O resultado foi um enfraquecimento da dorsal atlântica e a construção episódica de vales planéários ao largo da Europa.

No mês de Março, pelo contrário, a circulação de altitude foi Je uma grande simplicidade, predominando um fluxo zonal de oeste, ligeiramente ondulado $\left(^{(5)}\right.$, que dirigia para a Península as perturbações da frente polar. Todlavia, Portugal foi, por via de regra, afectado apenas pelas caudas dessas depressões; por isso as chuvas ocorridas foram geralmente fracas, com excepção das da última década do mês.

OS TIPOS DE ANTICICLONES, SUA SUCESSÃO E FREQ̈UÊNCIA DE OCORRÊNCIA - As condições de abrigo aerológico que dominaram em Portugal, desde meados de Novembro de 1980 a finall de

(8) Situação, aliás, pouco comum no mês de Março, em que domina, por via de regra, a circulação meridianà. Pelo contrário, a circulação zonal rápida costuma ser uma característica fundamental dos meses de Inverno. Sobre a circulação atmosfériça da margem atlântica da Peninsula Ibérica, veja-se o importante trabalho de J. Mounies, Les climats océaniques des régions atlantiques de l'Espagne et du Portugal, Lille, 1979, 1221 p. polic. e um volume de figuras.

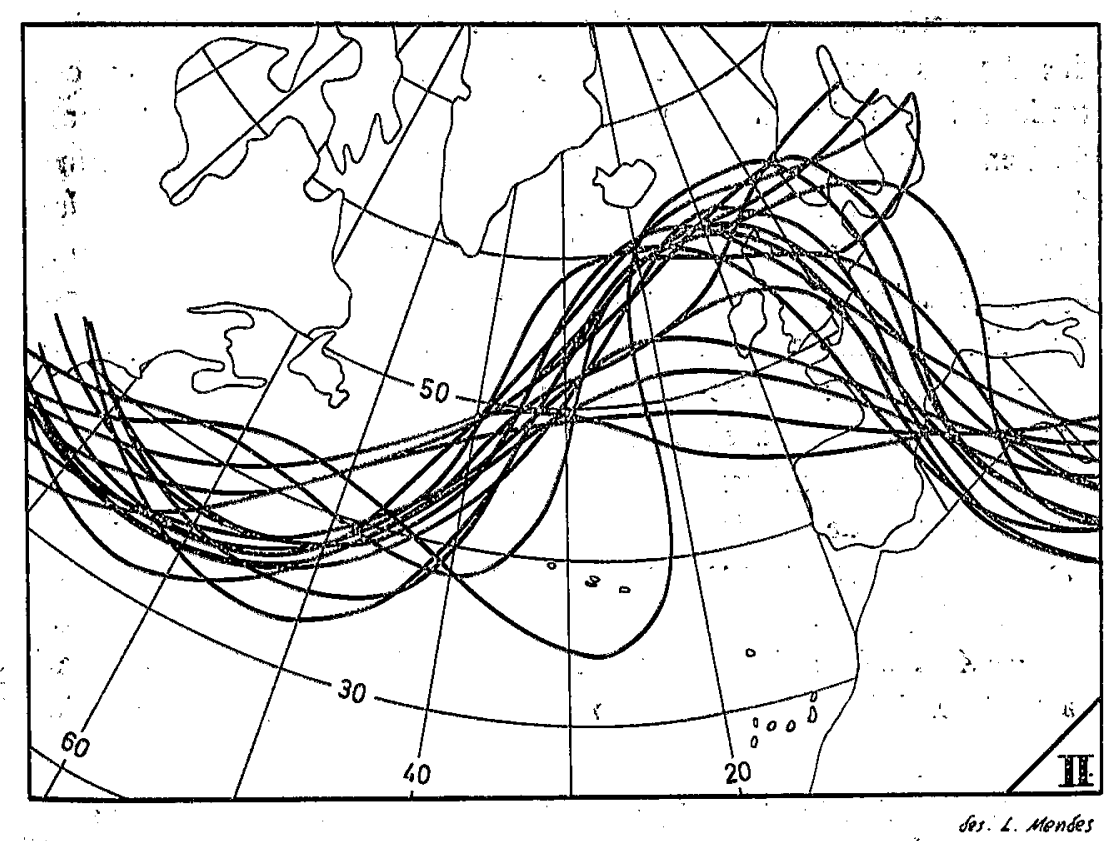

* Fig. 5-Trajectórias diárias do jet no Atlântico Norte. I-Dezembro de 1980; formação de correntes ondulatórias de fraca amplitude, com individualização de uma dorsal no Atlântico oriental; 11 - Janeiro de 1981; persistência 4 


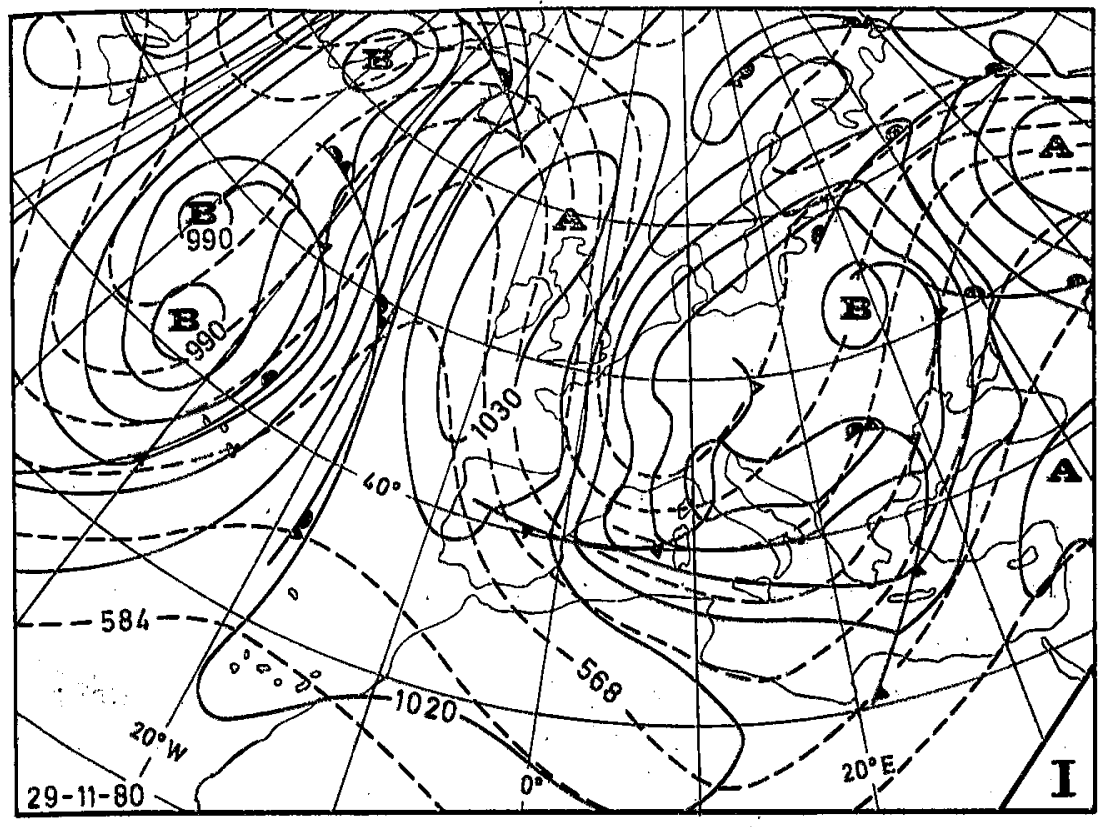

pressões não se estender ao Norte de Africa, fazendo afluir a Portugal um fluxo de ar polar de origem maritima, continentalizado sobre a Europa meridional e aquecido sobre o Mediterrâneo, antes de atravessar a Península.

No período analisado, não foi possívell identificar anticiclones exclusivamente térmicos sobre a Península Ibérica $\left({ }^{10}\right)$. Os anticiclones alimentados na base por uma massa de ar frio apresentam. a maior ou menor altitude, uma massa de ar submetida a subsidência dinâmica. Estes anticiclones mistos constiłuem, de certo modo, prolongamentos setentrionais dos anticiclones subtropicais, separados destes, por vezes, por descontinuidades frontais internas. Consideram-se os seguinte tipos:

- Anticiclone de fim de família (Az). Depois da passagem de uma família de depressões de oeste, dá-se uma descarga de ar frio polar em superfície, coincidindo, em altitude, com a formação de uma ligeira curvatura anticiclónica da corrente zonal. Trata-se de uma situação efémera e o tipo de tempo que ela origina confunde-se muitas vezes com $o$ dos sectores posteriores das frentes frias.

- Anticiclone atlântico misto ( $A$ a). $O$ acentuar e a persistência de uma ondulação positiva do fluxo de oeste no Attântico oriental vão permitir a transformaçăo do anticiclone de fim de família num anticiclone misto, o qual tem consequencias diferentes sobre o estado de tempo conforme a amplitude da dorsal. Assim, com uma dorsal pouco desenvolvida em latitude, o país é afectado por ar marítimo fresco e húmido, de ceste a noroeste (fig. 6-II).

- Anticiclone atlântico misto, em apófise polar $(A p)$. Em circulação meridiana lenta, a dorsal prolonga-se bastante para norte, dando origem, em superfície, a uma verdadeira apófise polar do anticiclone misto Aa. Nestas condições, Portugal é afectado por ar polar marítimo directo, de norte, bastante mais frio (fig. 7-I).

- Anticiclone atlântico misto prolongando-se até à Europa Ocidental (Aae). A evolução referida atrás é favorável ao prolon-

(10) Na sua classificação das estruturas sinópticas do sudoeste europeu, J. Mounier (ob. cit., p. 407-451) faz referência a anticiclones fouco espessos, de origem exclusivamente térmica. Note-se que essa classificação se aplica a um período de vinte anos e a uma escala espacial bem mais vasta do que nquela a que se refere o presente trabalho.

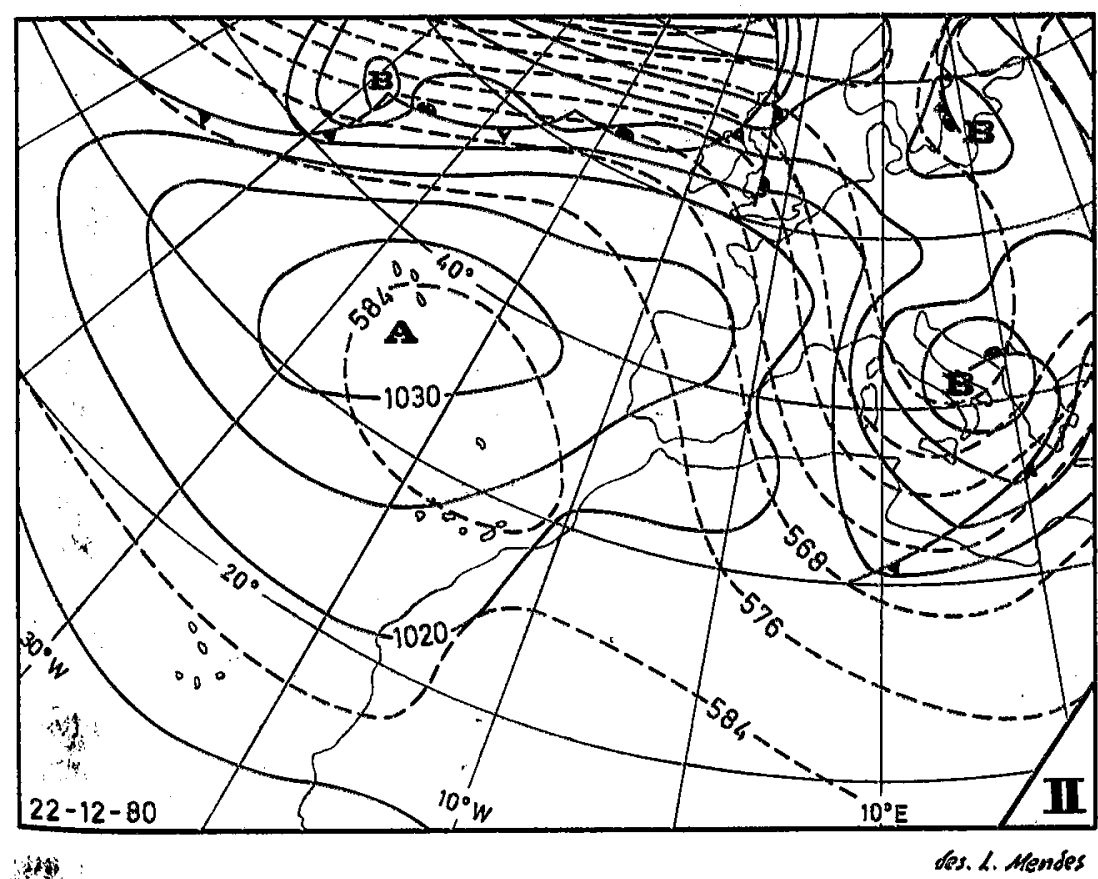

Fig. 7 - Anticiclone atlântico misto, em apófise polar (I) e anticiclone atlântico misto prolongando-se ligeiramente pela Europa Ocidental (II). 
gamento da célula anticiclónica atlântica em direcção à Europa. Enquanto a raiz do anticiclone atlântico misto fica bloqueada ao largo da Península, a sua apófise polar tende a deslocar-se lentamente para leste sob a influência da onda planetária, tomando o cixo da dorsal uma direcção aproximadamente NE-SW. Nestas condições, Portugal recebe um fluxo de ar polar marítimo, vindo de norte ou nordeste. Este ar tem já um percurso continental mais ou menos longo, de modo que o tipo de tempo originado por este anticiclone é já diferente do que resulta de uma célula exclusivamente marítima. No entanto, na maior parte dos casos, o país não é aincla afectado por ar polar continental, devido à descontinuidacle introduzida pelas perturbações que circulam ao longo da margem norte do anticiclone (fig. 7-II).

- Anticiclone atlântico ligado ao anticiclone térmico europeu $(A E)$. A progressăo do anticiclone atlântico misto sobre a Europa pode continuar, ao ponto de se unir ao anticiclone frio da Europa Central ou mesmo da Sibéria. Esta junção está intimamente ligada à evolução do vale planetário que se forma a jusante da dorsal attlântica. Durante o último Inverno, este vale foi muito profundo e persistente, tendo-se deslocado pouco em longitude. A invasão de ar árctico muito frio originou a formação de ciclones muito activos, tanto no Mar do Norte como no Mediterrâneo. No continente europeu, o vale marca-se em superfície apenas pela presença de um colo, mais ou menos perturbado, que isola o anticiclone dinâmico de origem atlântica do anticiclone térmico continental (fig. 8-I e 8-II). Interessa sublinhar que é justamente sobre os mares que a ciclogénese se desenvolve, devido à libertação de calor sensivel' e calor latente de vaporizaçăo. Assim, enquanto o Mar do Norte e o Mediterrâneo se encontram sob a influência persistente de uma depressão bastante intensa, as regiões europeias situadas sob o colo que marca a presença do vale pląnetário no seu percurso continental ficam sujeitas a perturbações frontäis, que ligam a depressão do Mar do Norte à clo Mediterrâneo. Estas frentes meridianas desempenham o mesmo papel da frente polar derivada, impedindo a advecção de ar polar continental muito frio até aos confins da Europa Ocidental. Pello contrário, $\log 0$ que a língua de ar frio de altitude, associada ao vale planetário, cortada da sua origem por um aumento de velocidade do fluxo zonal, o colo anticiclónico desaparece, desaparecem também as frențes meridianas e os dois anticiclones

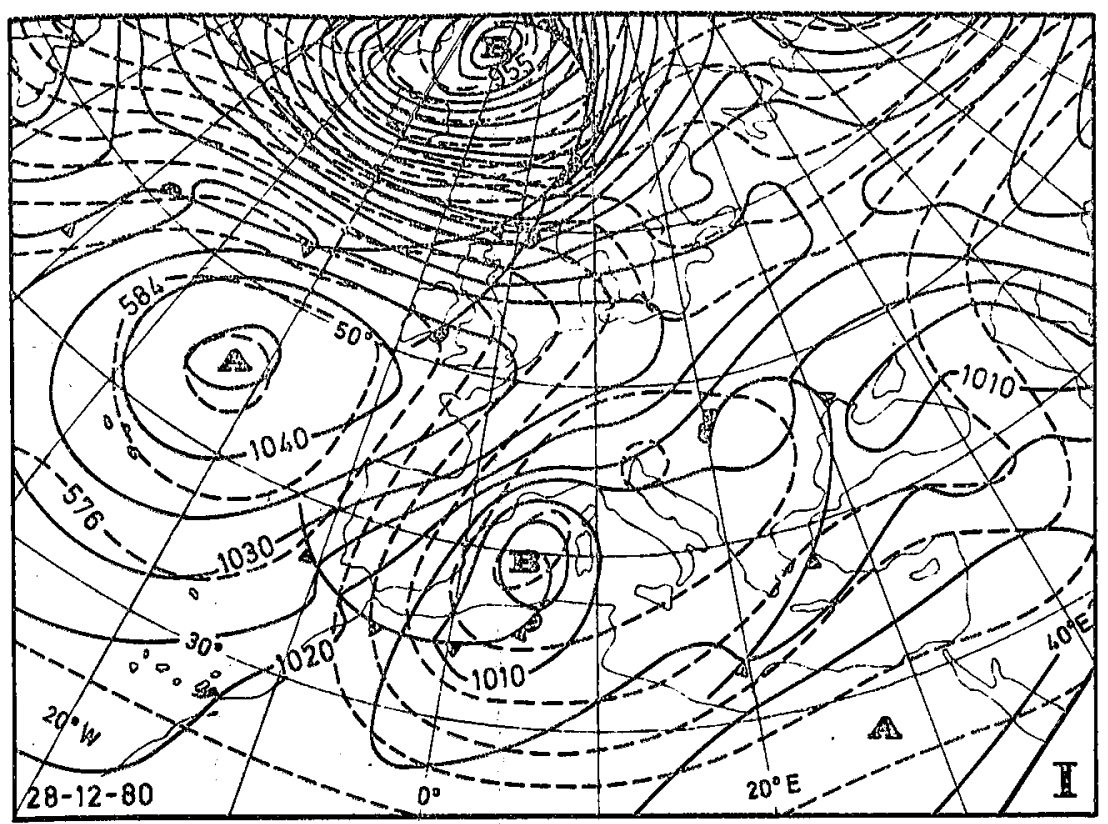

(i)

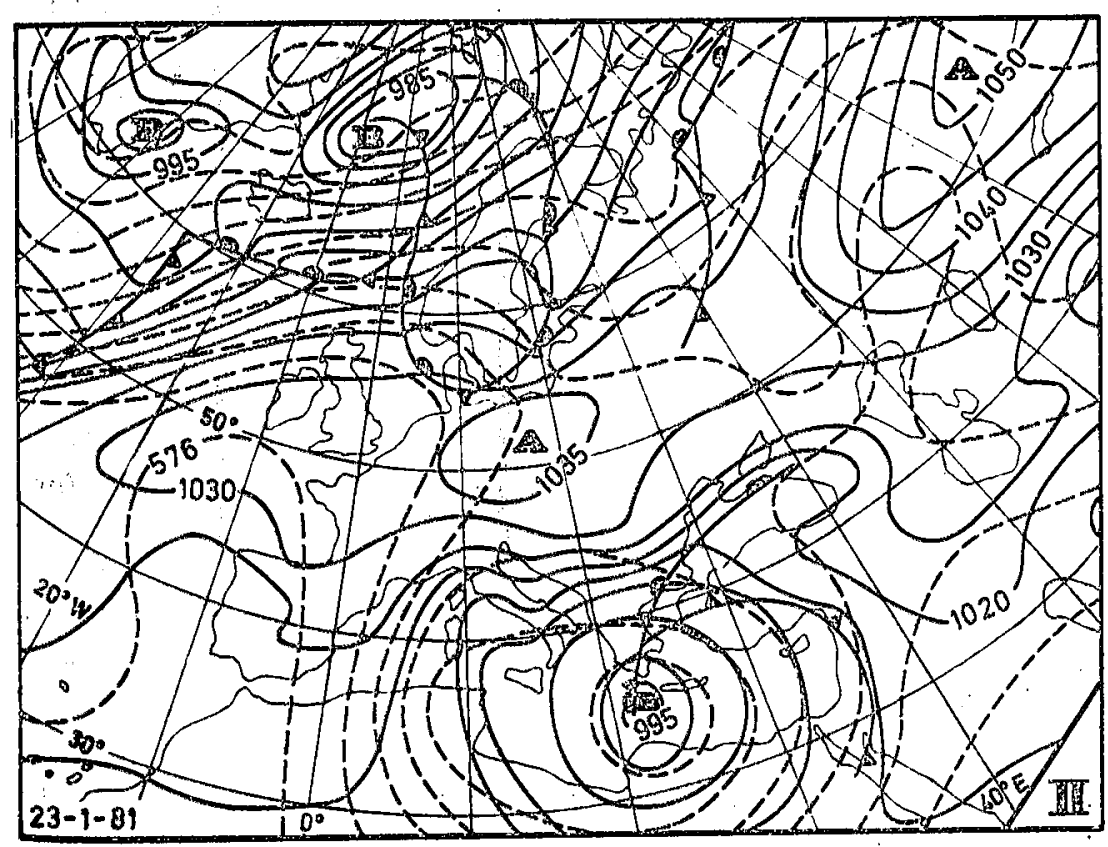

aps. L. Axpondes

Fig. 8-Anticiclone atlântico misto ligado ao anticiclone térmico europeu (I) e anticiclone atlàntico misto ligado a uma faixa cle altas pressões de origem ato térmica que se prolonga até à Sibéria (II). 
juntam-se em superfície, originando uma célula muito alongada em. longitude. Mesmo associadas, é fácil distinguir a origem destas duas células anticiclónicas: ao nível dos $500 \mathrm{mb}$, a célula ocidental, de origem dinâmica. é encimada por uma dorsal; pelo contrário, sobre a célula oriental, de origem térmica, encontra-se a própria corrente zonal, materializada por linhas de fluxo relativamente esparsas. Além disśo, em superfície, a célula ocidental raramente ultrapassa $1035 \mathrm{mb}$, enquanto a célula oriental pode atingir, no seu centro, pressões da ordem dos $1080 \mathrm{mb}$. Com a junção dos dois anticiclones junto ao solo, o ar polar continental chega à Península Jbérica com uma trajectória de nordeste a leste. Trata-se de um ar muito frio e muito seco.

Um dos aspectos mais marcantes da circulação atmosférica da. margem ocidental da Penínșila, durante o Inverno de 1980-81, foi a frequência de uma evoluçăo sinóptica em que uma dorsal exclusivamente atlîntica acaba por estender-se à Europa, depois recua de novo para o Atlântico orjental, diminuindo de amplitude. Em superfície assiste-se então ao. encadeamento dos seguintes anticiclones: Aa; Aae (eventualmente $A E$ ), Aa. Em média essa evolução durou cerca de uma semana. No período de 20 de Dezembro de 1980 a 12 de Janeiro de 1981 deu-se o encadeamento de três sequências, em que o anticiclune atlântico misto, embora de fraca amplitude, transbordava ainda sobre a Europa, de modo a permitir 0 . afluxo de ar com trajecto continental.

Essas sequências de anticiclones mistos podem ser interrompidas pela formação de um anticiclone quente. A cessação da alimentação de ar frio nas camadas inferiores do anticiclone atlântico misto, em virtude da presença, a norte, de uma corrente de perturbações da frente polar, provoca uma rápida desnaturação do ar polar, em contacto com o oceano. Assim, o anticiclone misto transforma-se num anticiclone constituído apenas por ar quente, embora de origens diversas. Mas estes anticiclones são geralmente efémeros, devido à recidiva das descargas polares, que levam à formação de um novo anticic'one misto. Foi o que aconteceu, por exemplo, de 3 a 5 de Fevereiro de 1981 (fig. 9). Em 3-2-81, uma vasta célula anticiclónica cobre o Atlântico oriental e a Europa mediterrânea. $O$ afluxo de ar frio em superfície é interrompido pela passagem de uma família de depressões que circulam na margem norte do anticiclone. Em 4-2-81, uma descarga polar, ao largo da Irlanda,
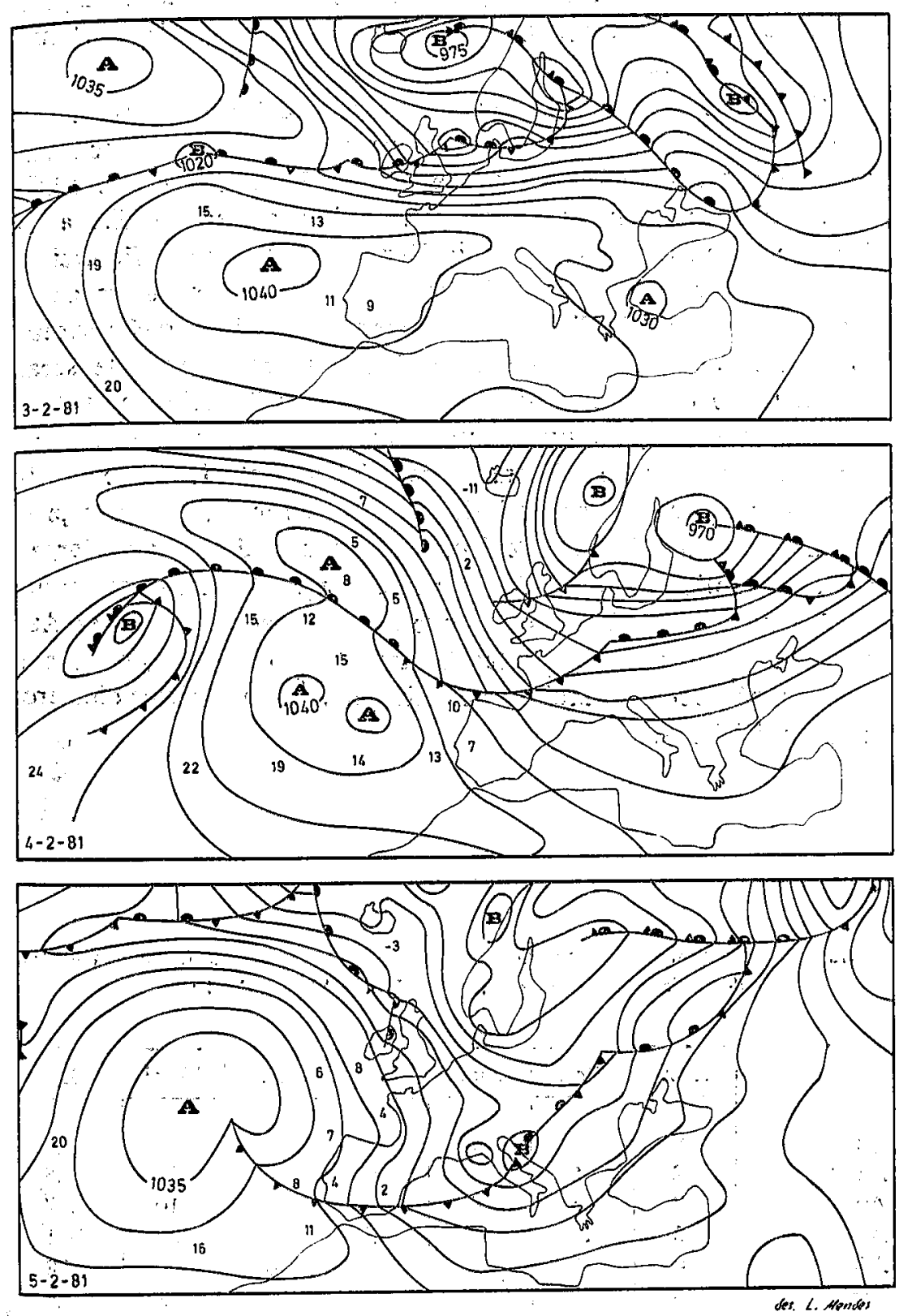

Fig. 9-Evolução de um anticiclone quente num anticiclone atlântico misto (indicam-se : algumas temperaturas observadas sobre o Atlântico). 
rompe a corrente de perturbações. Em 5-2-81, o ar frio começa a invadir o litoral português, provocando uma queda de $5^{\circ} \mathrm{C}$ nas temperaturas mínimas.

O quadro I indica a frequência de ocorrência, expressa em número de dias, dos diferentes tipos de anticiclones que afectaram Portugal desde 1 de Novembro de 1980 a 31 de Março de 1981. Repare-se, em primeiro lugar, no elevadíssimo número de dias anticiclónicos ocorridos nos meses de Dezembro, Janeiro e Fevereiro. Atendendo a que as 17 situações anticiclónicas de Novembro ocorreram todas depois do dia 13, fica-se com a ideia da duração excepcional das condições de abrigo aerológico responsáveis pela seca. O predomínio claro dos anticic'ones mistos $(73 \%)$ sobre os anticiclones quentes $(27 \%)$ é perfeitamente normal nos meses de Inverno. Dos anticiclones mistos, foram os de relativamente fraco desenvolvimento latitudinall, quer exclusivamente atlânticos ( $\mathrm{Aa}$ ) quer prolongando-se pela Europa Ocidental (Aae) que dominaram largamente. Os anticiclones $A E$ foram pouco frequentes e só ocorreram em Dezembro e em Janeiro. No que se refere aos anticiclones Az, uma contagem baseada na situação sinóptica observada de 24 em 24 horas, não pode ser muito elucidativa, devido ao carácter efémero desses anticiclones.

\section{QUADRO I}

Frequência de ocorrência (n..$^{\circ}$ de dias) dos diferentes tipos de anticiclones, de 1 de Novembro de 1980 a 31 de Março de 1981

\begin{tabular}{l|r|r|r|r|r|r|r}
\hline & Nov. & Dez. & Jan. & Fev. & Mar. & Total & $\%$ \\
\cline { 2 - 6 } & 0 & 6 & 1 & 1 & 3 & 11 & 9,6 \\
Az & 2 & 6 & 11 & 9 & 4 & 32 & 27,8 \\
Aa & 2 & 3 & 0 & 2 & 3 & 10 & 8,7 \\
Ap & 3 & 10 & 4 & 5 & 0 & 22 & 19,1 \\
Aae & 0 & 2 & 7 & 0 & 0 & 9 & 7,8 \\
AE & 3 & 0 & 0 & 0 & 0 & 3 & 2,6 \\
Am & 4 & 4 & 6 & 4 & 2 & 20 & 17,4 \\
AA & 3 & 0 & 0 & 0 & 5 & 8 & 7,0 \\
As & 17 & 31 & 29 & 21 & 17 & 115 & 100,0 \\
\hline Total & & & & & &
\end{tabular}

Os TIPOS DE TEMPO ANTICICLÓNICOS FRIOS. - Com a instalacão de anticiclones persistentes, a estrutura da atmosfera foi particularmente estável na Península, durante o Inverno de 1980-81. cularmente estável na Península, duránte a uma altitude mais ou menos elevada, em função da natureza dos anticiclones (fig. 10).

Em Az e Aa, a existência de uma camada relativamente espessa de ar húmido instável, na baixa troposfera, permite o desenvolvimento de estratos e estratocúmulos (fig. 10-A), o que explica em parte a elevada nebulosidade das regiões litorais durante este Inverno e, mesmo, a formação de chuvas fracas nas regiões montanhosas. As descidas de temperatura foram normalmente ritmadas pelo prolongamento da crista anticic'ónica do Atlântico oriental até latitudes bastante setentrionais ou pela sua extensão ao continente europeu. Nestas condições, as temperaturas mínimas, em abrigo, podem atingir valores negativos, mesmo em estações litorais do Norte, como sejam Viana do Castelo e Porto.

A evolução sinóptica inicada em 20 de Dezembro de 1980 pode servir de exemplo desse fenómeno. Nesse dia, o país encontra-se sob a influência de um anticiclone Aa (fig. 6-II), que transporta ar polar marítimo de retorno e, por isso. as temperaturas observadas são suaves, com fracas amplitudes térmicas e fracos contrastes regionais (quadro II). Nestas condições, a camada inferior de ar instável e húmido é espessa, dando origem a céu encoberto e chuva nalguns locais (fig. 11-A). Com o alongamento progressivo do anticiclone atlântico para leste, o ar polar chega com um percurso continental mais ou menos longo, o que se reflecte num abaixamento muito sensivel da temperatura. Em 26 de Dezembro, as temperaturas mínimas são inferiores a $5^{\circ} \mathrm{C}$ nas regiões interiores, o que corresponde a uma descida de cerca de $10^{\circ} \mathrm{C}$ relativamente às do dia 20 . As regiões litorais, sob a influência directa do oceano, registam temperaturas menos baixas, havendo, no entanto, uma descida geral da ordem dos 5 a $6^{\circ} \mathrm{C}$. Em 29 de Dezembro o anticiclone estende-se até à Europa Central. Nestas condições, Portugal é atingido por uma vaga de frio que abrange mesmo as regiões litorais (quadro II e fig. 11-B).

i Devido ao longo trajecto continental, o ar polar chega bastante seco, a nebulosidade é fraca ou nula e o arrefecimento nocturno é muito intenso. Assim, à inversão de origem dinâmica junta-se uma inversão de origem térmica, que resulta da advecção do ar frio e 


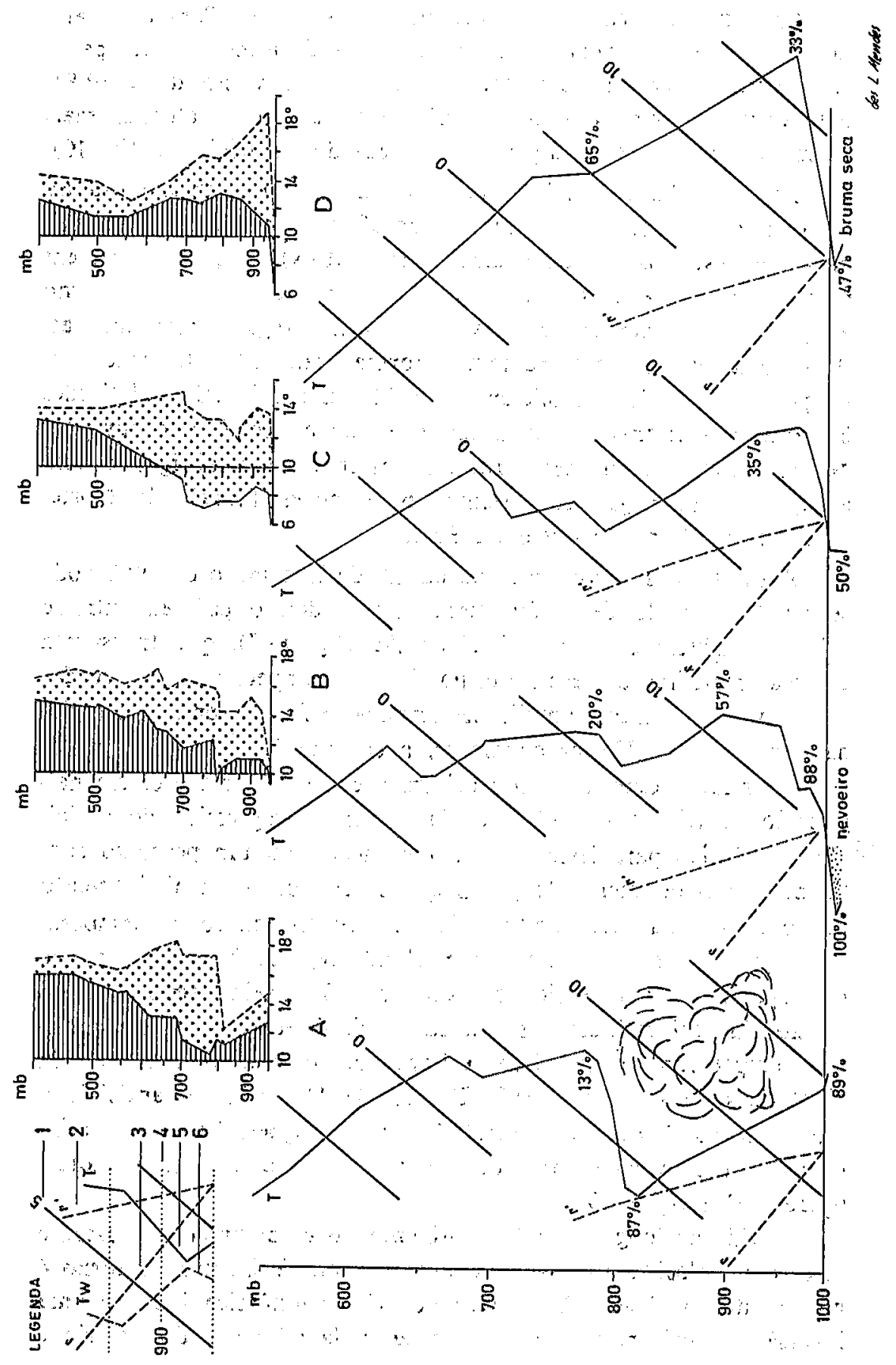

QUADRO II

Evolução das temperaturas na passagem de um anticiclone atlântico a um anticiclone estendendo-se a Europa Central

\begin{tabular}{l|rr|r|r|r|r}
\hline & \multicolumn{2}{|c|}{$20 / 12$} & \multicolumn{2}{c|}{$26 / 12$} & \multicolumn{2}{c|}{$29 / 12$} \\
\cline { 2 - 7 } & Min. & Máx. & Min. & Máx. & Min & Máx. \\
\hline Viana do Castelo & 14 & 15 & 9 & 13 & -2 & 15 \\
Bragança & 10 & 13 & -2 & 8 & -5 & 9 \\
Porto & 12 & 14 & 4 & 13 & -1 & 12 \\
Vila Real & 11 & 14 & 0 & 9 & 0 & 9 \\
Coimbra & 12 & 14 & 4 & 15 & 3 & 12 \\
Cabo Carvoeiro & 7 & 15 & 7 & 12 & 6 & 13 \\
Portalegre & 9 & 12 & 6 & 11 & 0 & 9 \\
Lisboa & 13 & 13 & 9 & 15 & 4 & 12 \\
Evora & 11 & 14 & 6 & 14 & 1 & 11 \\
Beja & 12 & 17 & 2 & 16 & 0 & 13 \\
Sines $\because$ & 14 & 15 & 9 & 15 & 4 & 14 \\
Sagres $\because \therefore$ & 14 & 17 & 11 & 16 & 8 & 13 \\
Faro & 13 & 18 & 5 & 18 & 6 & 16 \\
\hline
\end{tabular}

aid is

Fig. 10 - Estrutura da troposfera em diferentes situações anticiclónicas e suas consequências (sondagens em Lisboa, às 12 TMG). A-Em 20-12-80, sob a influência de um anticiclone atlântico misto. (Aa), đlạ́-se uma invasão do ar húmido e fresco na baixa troposfera, com formação de estratocúmulos. $\mathrm{B}-\mathrm{Em}$ 14-12-80, sob a influêncin de um anticiclone atlântico estendendo-se até à Europa Ocidental (Aae), a inversão térmica é muito baixa; todavia, uma forte humidade nas baixas camadas da atmosfera permite a formação de nevoeiros persistentes. $\mathrm{C}$ - Em 31-12-80, sob a influência de um $\mathrm{AE}$, inversão térmica muito baixa e secura feneraljzada. D-Em 27-1-80, sob a influência de um AA, invasão de ar sariano e formacão de brumas secas. Legenda comum às figs. 10,11 e 12: 1 - isotérmica, de $5 \mathrm{em} 5^{\circ} \mathrm{C} ; 2$ - adiabática húmida; 3 - adiabática seca; 4-isóbara, de $50 \mathrm{em} 50 \mathrm{mb} ; 5$-curva de estado da temperatura; 6-curva da pseudotemparatura do termómetro moḷado. No diagrama de massa de ar, a linh continua representa a variação com a pressão da pseudotemperatura potencial do termómetro molhado; a linha descontínua representa a variação com a pressão de uma temperatura fictícia, corresponclente à temperatura a que ficaria uma partícula da massa de ar, considerada inicialmente saturada, a úma determinada pressão, e levada por um processo adiabático húmido até ao nível dos $1000 \mathrm{mb}$. Quanto maior for a distância entre as duas curvas (área ponteada), maior é a secura do ar. A distinção entre as massas de ar quente e frio é feita em função da abcissa de $100^{\circ}$. 


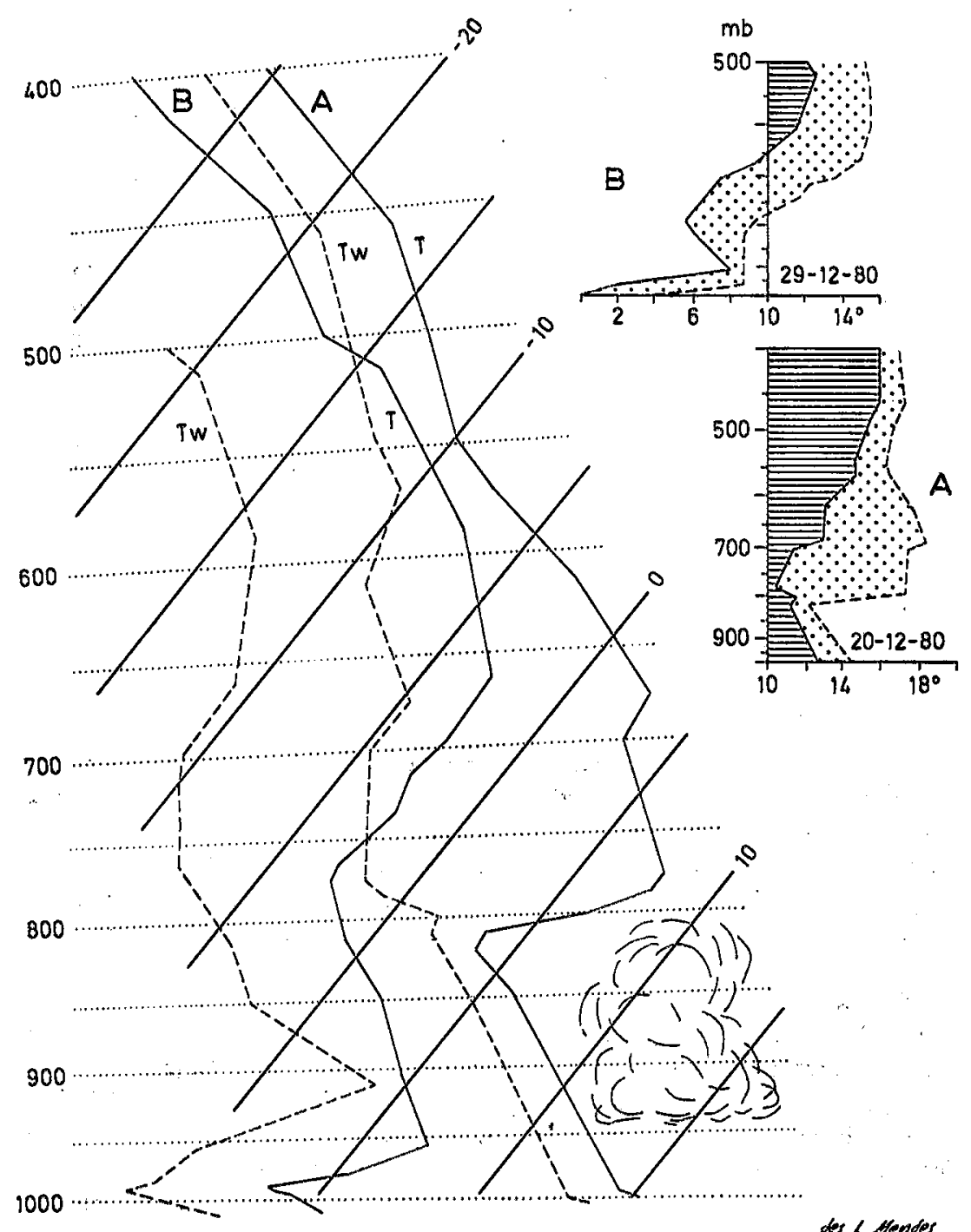

Fig. 11 - Arrefecimento da baixa e média troposfera na passagem de um anticiclone $A a(A)$ a um anticiclone $A E(B)$. da forte radiação nociurna. A configuração topográfica pocle também contribuir para a intensificação destas inversões térmicas. Devido ao arrefecimento nocturno, a camada de ar em contacto com o solo arrefece também, torna-se mais densa e desliza ao longo das vertentes, indo acumular-se nos vales e nas depressões, onde estagna. $O$ ar das regiões altas, em contacto com a superfície do solo é, assim, constantemente renovado, o mesmo não acontecendo nas regióes deprimidas. Compreende-se que, sob a influência de anticiclones particularmente estáveis, as inversões de temperatura sejam um fenómeno banal nas regiões montanhosas e atinjam, por vezes, valores muito elevados. O boletim meteorológico diário dá muito pouca informação a este respeito. A única estação de altitude nele referida é Penhas Douradas e apenas com duas observações diurnas, uma às $12 \mathrm{~h}$ e outra às $18 \mathrm{~h}$, que não permitem a ava! iação das tem. peraturas mínimas. Mesmo assim, comparando as temperaturas registadas às $12 \mathrm{~h}$ em Bragança $(691 \mathrm{~m})$ e em Penhas Douradas $(1380 \mathrm{~m})$, é possível fazer ideia da amplitude das inversões térmicas. O período de 1 a 9 de Janeiro de 1981 (quadro III e fig. 12) é, a este respeito, bastante elucidativo.

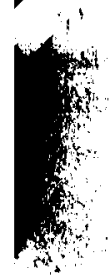

\section{QUADRO III}

- Inversões de temperatura, entre Penhas Douradas $(1380 \mathrm{~m})$ e Bragança $(691 \mathrm{~m})$, no periodo de 1 a 9 de Janeiro de 1981 (indicam-se as temperaturas observadas em cada uma das estações, às 12 TMG)

\begin{tabular}{c|c|c|c}
\hline Dia & Penhas Douradas & Bragança & Valor da inversão \\
\hline 1 & 14 & 3 & 11 \\
2 & 12 & 5 & 7 \\
3 & 13 & -1 & 14 \\
4 & 12 & -2 & 14 \\
5 & 10 & -2 & 12 \\
6 & 8 & 1 & 7 \\
7 & 10 & -3 & 13 \\
8 & 10 & 2 & 8 \\
9 & 11 & 6 & 5 \\
\hline
\end{tabular}




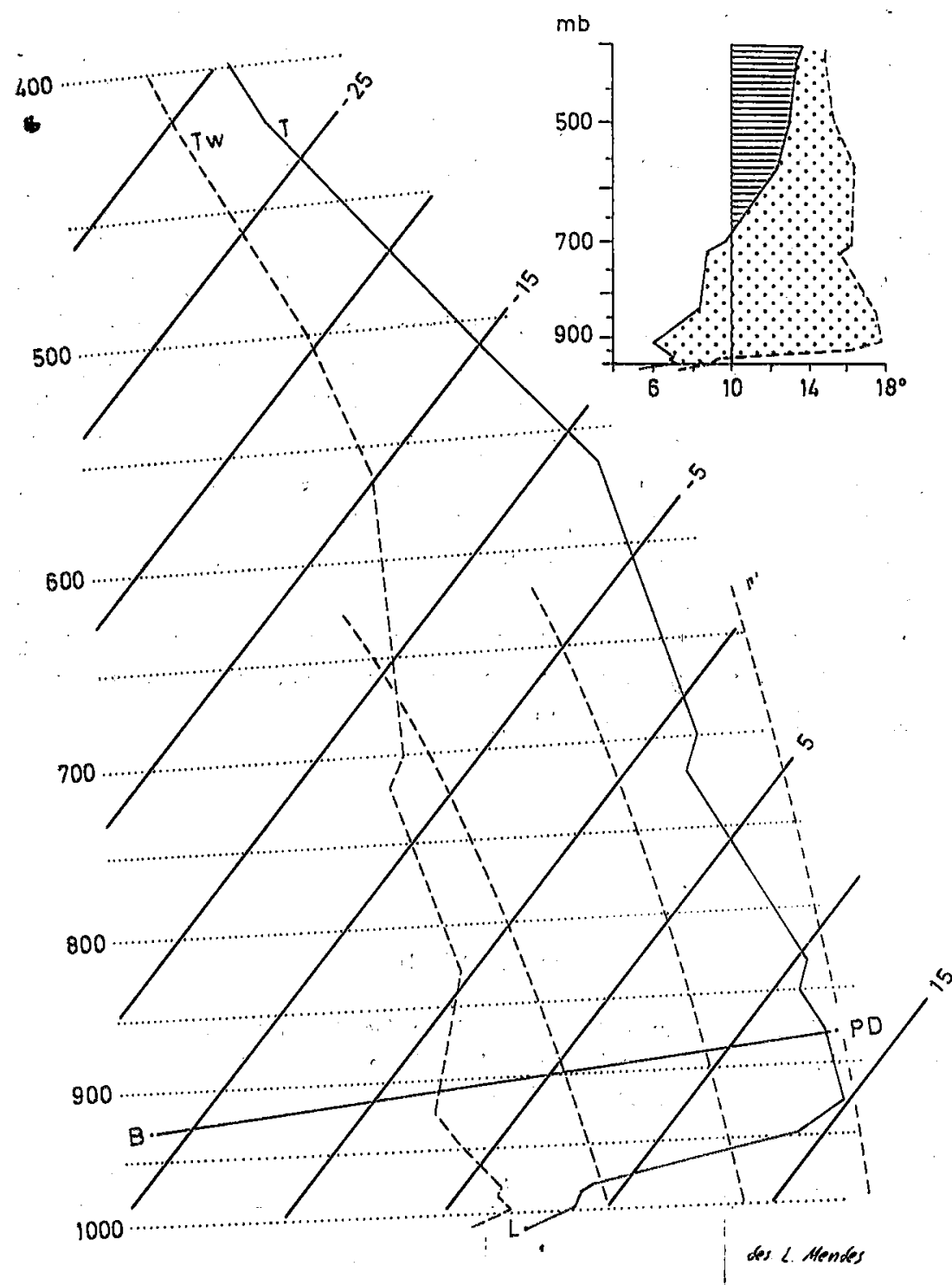

Fig. 12 - Exemplo de uma forte inversão térmica na bacia de Bragança (3-1-81, anticiclone Aae). A figura representa a sondagem em Lisboa ( $L$ ), às $12 \mathrm{TMG}$, sobre a qual se localizaram, ìs altitudes respectiyas, as temperaturas observadas em Bragança (B) e em Penhas Douradas (PD), à mesma hora. A inversão de radiação é posta em evidência pelo fortíssimo gradiente térmico negativo entre Bragança e Penhas Douradas. $O$ grande arrefecimento na bacia de Bragança levou à formação de nevoeiro gelado.
1. Nos anticiclones Aae, AE e AA, a camada húmida inferior praticamente desaparece: as sondagens mostram uma sụbsidência generalizada e a inversão é particularmente baixa (fig. 10). Nas regiōes litorais, a película de ar sob a inversão térmica carregamse de vapor de água sobre o oceano, mas a propagação das partículas em altitude é impossivel: daí uma má visibilidade, devido à ocorrência de brumas ou de nevoeiros.

- Se as temperaturas. forem suficientemente baixas e a agitação do ar for muito fraca, formam-se geadas. Na falta de clados de temperatura junto ao solo, pode considerar-se como dias de possivel ocorrência de geadas aqueles em que a temperatura mínima, registada em abrigo, for inferior a $5^{\circ} \mathrm{C}$ : O quadro IV mostra grandes diferenças entre as estações meteorológicas, traduzindo a importância das condições geográficas, juntamente com as situações meteorológicas, nas manifestações do frio. As maiores diferenças verificam-se, como seria de esperar, entre as estações do Norte e as do Sul, por um lado, e as estações do litoral e as do interior, por outro. De notar o elevado número de dias com temperatura mínima inferior a $5^{\circ} \mathrm{C}$ em Viana do Castelo, apesar de se tratar de uma estação litoral. Os resultados obtidos em Bragança não surpreendem, dada a sua posição no Nordeste e numa área deprimida, rodeada søbretudo a norte e a oeste, por montanhas bastante altas.

\section{QUADRO IV}

Número de dias com temperatura mínima inferior a $5^{\circ} \mathrm{C}$ (em: abrigo) durante o semestre de Outubro de 1980 a Março de 1981

\begin{tabular}{|c|c|c|c|c|c|c|c|}
\hline & Out. & Nov. & Dez. & Jan. & Fev. & Mar. & Total \\
\hline Viana do Castelo & 3 & 8 & 19 & 17 & 15 & 2 & 64 \\
\hline Braganca & 4 & 18 & 25 & 29 & 25 & 9 & 110 \\
\hline Porto & 1 & 6 & 17 & 12 . & 14 & 2 & $\$ 2$ \\
\hline Vila Real & 3 & 12 & 23 & 24 & 21 & 5 & 88 \\
\hline Coimbra & 0 & 5 & 18 & 10 & 8 & 3 & 44 \\
\hline Cabo Carvoeiro & 0 & 0 & 2 & 1 & 1 & 0 & 4 \\
\hline Portalegre & 0 & 5 & 11 & 5 & 11 & 0 & 32 \\
\hline Lisboa & 0 & 2 & 8 & 6 & 4. & 0 & $20^{\prime}$ \\
\hline Evora & 0 & 4 & 11 & 6 & 7 & 0 & 28 \\
\hline Beja & 0 & 5 & 15 & 17 & 12 & 2 & 51 \\
\hline Sines & 0 & 0 & 4 & 1 & 1 & 0 & 6 \\
\hline Sagres & 0 & 0 & 0 & 0 & 0 & 0 & $\mathrm{u}$, \\
\hline Faro & 0 & 2 & 5 & 14 & 6 & 0 & 27 \\
\hline
\end{tabular}


Mas os valores obticlos em cada uma dessas estações meteorotógicas, embora possam ser significativos quanto aos riscos de formação de geadas nesses lugares, não permitem uma generalização rigorosa a outras áreas. Bastam, por vezes, ligeiras modificações da topografia para que os perigos de geada sejam diversos. Este fenómeno verificou-se, por exemplo, durante o Inverno de 1980-81, nos laranjais do Ribatejo: na região de Chamusca, as laranjeiras situadas em posição topográfica deprimida ficaram muito danificadas (folhas engelhadas e queda de frutos), enquanto as que se encontravam em posição de vertente escaparam ao flagelo da geada negra.

De uma maneira geral, pode dizer-se, todavia, que os anticic'ones responsáveis pela ocorrência de geadas foram sobretudo os Ap (raros), Aae e AE. Os anticiclones $A z$ e Aa transporiam ar polar marítimo, com temperaturas não muito baixas e com humidade suficientemente elevada para que o céu se cubra de nuvens, impedindo um importante arrefecimento nocturno. As, constituído unicamente por ar quente dá origem a temperaturas mínimas bástante altas. Com $\mathrm{AA}$ e $\mathrm{Am}$, as geadas não são impossíveis, devido à forte radiação nocturna, mas elas săo raras e limitadas a condições locais particulares. Aliás, estas condições locais podem ser de tal modo determinantes que desvanecem, nas manifestações do frio, as diferenças entre os anticiclones. Isso mesmo aconteceu em Bragança durante o período de frio muito intenso que se verificou entre 29 de Dezembro e 8 de Janeiro: embora seguinclo-se à influência de anticiclones Aae e $A E$, que permitiram a acumulação de ar frio nas depressões do interior, esse período coincidiu em grande parte com anticidlones Aa, apenas com um ligeiro prolongamento pela Europa Ocidental ( $\left.{ }^{11}\right)$.

\section{O Outono de 1981 e o fim da seca}

Do ponto de vista da precipitação, pode considerar-se a Primavera de 1981, no conjunto, próxima do normal. Todavia. o esgotamento estival das reservas de água no solo foi majs precoce do que

(ii) Neste trabalho, tem-se dado atencão à origem, cotrutura e conse quências dos anticiclones. Mas os riscos de geada existem tambśm, embora com menor acuidade, em situações ciclónicas. é habitual (fig. 3 e 4 ), em consequência da situação deficitária dessas reservas durante o Inverno precedente. A deficiência de evaporação (ETP-ETR) no Verão de 1981 foi particularmente elevada, devido a três razões fundamentais: o já citado esgotamento precoce das reservas de água no solo, precipitação praticamente nula em quase todo o país e temperaturas anormalmente elevadas.

O mês de Setembro foi relativamente chuvoso, sobretudo no Norte do país. Outubro foi um mês próximo do normal no Norie e Centro, mas geralmente seco no Sul. Em Novembro, um dos meses normalmente mais chuvosos do ano, a precipitação foi praticamente nula em todo o país: $0 \mathrm{~mm}$ em Viana do Castelo, Bragança e Coimbra, $4 \mathrm{~mm}$ em Penhas Douradas, $3 \mathrm{~mm}$ em Lisboa, $4 \mathrm{~mm}$ em Évora. $2 \mathrm{~mm}$ em Beja e em Faro. Nas estações do Norte nunca tinham ocorrido precipitações tăo escassas no mês de Novembro, ẹquanto nas estações do Sul apenas duas ou três vezes, durante o presente século, os valores registados foram mais baixos. A falta de chuva fazia-se sentir, aliás, desde o princípio dá segunda semana de Outubro e prolongou-se até no final da primeira semana de Dezembro. Este facto reflectiu-se numa anormal escassez de água no solo no final do Outono de 1981, assim como num atraso no início do escoamento no ano hidro'ógico de 1981-82. A chuva viria a cair com grande abundância a partir da segunda semana de Dezembro, pondo termo a uma situação deficitária que durava há mais de um ano (fig. 3 e 4 ).

No quadro $V$ indica-se a frequência de ocorrência, expressa em "número de dias, dos vários tipos de anticiclones que afectaram Portugal, desde 1 de Novembro de 1980 a 31 de Dezembro de 1981. A simp'es consideração do número total de dias, em cada mês, com síuação anticiclónica, é bastante concludente. $O$ declínio da seca outono-invernal de 1980-81 está bem expresso no número de situações anticiclónicas ocorridas em Fevereiro (21), Março (17) e Abril (8). A evolução verificada de Abril a Agosto pode considerar-se normal: aumento considerável das situações anticiclónicas, ao mesmo tempo que se processa uma mudança da natureza dos anticictiones, desaparecendo os anticiclones mistos $\mathrm{AE}$ e Aae, enquantu os anticiclones subtropicais, já bastante frequentes em Maio e Junho, se tornaram largamente dominantes em Julho e Agosto. Setembro marca normalmente um declínio no abrigo aerológico proporcionado pelos anticiclones subtropicais e foi isso que aconteceu 


\section{QUADRO V}

Frequencia de ocorrênçia (n. ${ }^{\circ}$ de dias) dos diferentes tipos de anticiclones, de 1 de Novembro de 1980 a 31 de Dezembro de 1981

\begin{tabular}{l|r|r|r|r|r|r|r|r|r|r|r|r|r|r}
\hline & Nov. & Dez. & Jan. & Fev. & Mar. & Abr. & Mai. & Jun & Jul. & Ago & Set. & Out. & Nov. & Dez. \\
\hline Az & 0 & 6 & 1 & 1 & 3 & 0 & 3 & 0 & 2 & 0 & 2 & 1 & 0 & 0 \\
Aa & 2 & 6 & 11 & 9 & 4 & 3 & 3 & 7 & 2 & 2 & 1 & 6 & 5 & 1 \\
Ap & 2 & 3 & 0 & 2 & 3 & 3 & 0 & 2 & 2 & 0 & 0 & 1 & 0 & 1 \\
Aae & 3 & 10 & 4 & 5 & 0 & 2 & 0 & 0 & 0 & 0 & 0 & 0 & 0 & 0 \\
AE & 0 & 2 & 7 & 0 & 0 & 0 & 0 & 0 & 0 & 0 & 0 & 0 & 0 & 0 \\
Am & 3 & 0 & 0 & 0 & 0 & 0 & 0 & 4 & 0 & 4 & 3 & 5 & 1 & 0 \\
AA & 4 & 4 & 6 & 4 & 2 & 0 & 0 & 0 & 0 & 0 & 0 & 1 & 19 & 0 \\
As & 3 & 0 & 0 & 0 & 5 & 0 & 7 & 9 & 19 & 21 & 11 & 9 & 3 & 4 \\
\hline Total & 17 & 31 & 29 & 21 & 17 & 8 & 13 & 22 & 25 & 27 & 17 & 23 & 28 & 6 \\
\hline
\end{tabular}

em 1981. Mas essa evolução normal foi interrompida a partir da segunda semana de Outubro. O carácter excepcional do Outono de 1981 está bem patente no número muito elevado de situações anticiclónicas ocorridas em Outubro (23) e, sobretudo, em Novembro (28). Mais concretamente, entre 7 de Outubro e 5 de Dezembro i60 dias) houve apenas quatro dias com situação depressionária.

Para melhor definir o carácter excepcionall do Outono de 1981, do pon:o de vista da circulação atmosférica, fez-se a análișe das situações sinópticas ocorridas no mês de Novembro, durante vinte anos $\left({ }^{12}\right)$, desde 1962 a 1981 inchnsive. Verificou-se que, durante esses vinte anos, a média de dias anticiclónicos no mês de Novembro foi de 16 , sendo de 15 a mediana e também a moda. $O$ mínimo ocorreu em 1963, com 6 dias, e o máximo precisamente em 1981, com 28 dias anticiclónicos. Globalmente, os anticiclones mistos atingiram $43 \%$ das situaçốes anticiclónicas, umas vezes com fraco desenvolvimento latitudinal, circunscritos no oceano $(\mathrm{Aa}=17 \%)$ ou prolongando-se pe'a Europa Ocidental (Aae $=15 \%$ ), outras vezes constituindo uma apófise polar que canaliza para 0 ocidente

(12) Essa análise baseou-se no boletim meteorológico diário português. da Península ar polar marítimo directo $(\mathrm{Ap}=11 \%)$. Os anticiclones atlânticos subtropicais (As) perfizeram $14 \%$ das situações anticiclónicas, enquanto os anticiclones ibero-mediterrâneos (Am) e os ibero-africanos (AA) ocorreram em proporções idênticas, alcancando no total: $43 \%$, ou seja, uma percentagem igual à dos anticiclones atlânticos mistos, tomados em conjunto. A originalidade do mês de Novembro de 1981 , do ponto de. vista da circulaçăo atmosférica, foi a grande persistência (19 dias) dos anticiclones ibero-africanos, os quais para além de impedirem a ocorrência de chuvas, foram responsáveis por importantes anomalias positivas da temperatura em todo o país.

\section{CONCLUSÃO}

Os tipos de tempo de estação fria na Península Ibérica estão intimamente relacionados com os dispositivos da circulação atmosférica de.altitude. Em circulação zonal rápida, a frente polar atinge com frequência as latitudes da Península, durante períodos longos, dando origem a chuvas importantes. Em circulação meridiana, o dispositivo «normal» no hemisfério norte compreende um vale planetário a jusante das Montanhas Rochosas, uma dorsall no Atlântico e um outro vale na Europa Ocidental (13). As deslocações dos eixos das ondulações podem ser pequenas, mas tanto basta para collocar a Península Ibérica quer em situação de abrigo aerológico quer sob a influência de línguas de ar frio islandesas. gronelandesas e mesmo canadianas, as quais atravessam o Atlântico sob 0 impulso da corrente zonal. Estas línguas de ar frio são por via de regra geradoras de grande instabilidade. Foi o que aconteceu, de maneira particularmente acentuada, nas estações frias de 1976-77, 1977-78 e 1978-79, tendo-se registado valores de precipitação excepcionalmente altos. Uma mudança de amplitude das ondulações, em circulação meridiana, ou um percurso mais setentrional do jet pollar, em circulaçăo zonal, podem ter como consequência afastar da Península Ibérica as trajectórias das depressões. Resultam perío(1)

(13) Ver, entre outros trabalhos, o de L. P. STARK, "Positions of monthly mean throughs and ridges in the Northern Hemisphere», Monthly Weather Review; vol. 93, Boston, 1965, p. 705-720. 
dos de chuva fraca ou nula, que podem durar vários dias ou mesmo a'gumas semanas. Foram situações deste tipo, anormalmente persistentes, que estiveram na origem da fraca precipitação ocorrida desde meados de Novembro de 1980 a final de Fevereiro de 1981. A grande escassez das chuvas do Inverno de 1980-81 foi agravada por um Verão particularmente quente e seco e pela quase ausência de precipitações desde meados de Outubro até ao princípio de Dezembro de 1981. Em Novembro, um dos meses habitualmente mais chuvosos do ano, a precipitação foi praticamente nula de norte a sul do pais. Este facto ficou a dever-se, sobretudo, t̀ duração anormal de uma situação que não é desconhecida no Outono: a instalação de um anticiclone ibero-africano, ligado a uma dorsal planetária em altitude, que faz afiuir a Portugal um fluxo de sul ou sueste, de ar marítimo continentalizado ou de ar tropical continental, de origem africana; nestas condições não chove e a tem. peratura é anormalmente elevada.

A análise que acaba de ser feiıa mostra também a grande diversidade que as situações anticiclónicas de Inverno podem apresentar na margem atlântica da Península. Assim. não admira que nos vários anticiclones não corresponda um tipo de tempo bem definido. Tudo depende da sua estrutura, amplitude e disposição $\mathrm{cm}$ superfície. Um anticiclone centrado sobre o Atlântico orienta? tanto pode dar origem a um tempo fresco e húmido com formação de nuvens, eventualmente de chuvas fracas (Aa), como determinar temperaturas suaves e ocorrência de nevoeiros (As). Uma inflexão para nordeste do eixo do anticiclone misto atlântico pode fazer afluir ar muito frio e seco, de origem continental (Aae, AE), em vez do ar húmido e relativamente tépido, de origem atlântica. Numa situação deste tipo, a diversidade geográfica regional e local exprime-se com muita nitidez: a proximidade imediata clo oceano pode desnaturar rapidamente $o$ ar frio a seco de origem continental, enquanto este se acumula e persiste nas depressões interiores; aliás, se a estabilidade do ar for muito acentuada, pequenos contrastes de altitude, exposição ou da configuração topográfica são por vezes suficientes para que as manifestações do frio sejam bastante diversas.

Um problema, de muito interesse, que se poderia pôr, é o de saber em que medida esta seca se insere no ritmo normal do clima do país ou corresponde a uma manifestação d̄e uma mudança re- cente do próprio ritmo climático de Portugal. Não estamos ainda em condições de poder responder com alguma segurança a esta questão. Todavia, a ocorrência recente de anos particularmente húmidos (1976-77, 1977-78, 1978-79) e de anos anormalmente secos (1974-75, 1975-76, 1980-81), sugere uma tendência para o aumento da frequência da circulação meridiana e de bloqueio. tendência que parece verificar-se nas latitudes médlias do hemisfério norte, particularmente na margem oriental do Attântico e na Europa Ocidental. a partir de $1960\left({ }^{(14}\right)$.

\section{RESUMÉ}

La sécheresse de 1980-81 au Portugal. Causes météorologiques et types de temps. L'année hydrologique de 1980-81 a été une des plus sèches au Portugal depuis le début des registres météorologiques, avec des conséquences graves sur l'agriculture, l'élevage et la production d'électricité. L'évolution des précipitations et du bilan hydrique dans quelques stations, choisies de manière à donner une image de la variété régionale, permet de suivre le caracière exceptionñeí du phénoomène (fig. 1 aे 4). Le fait le plus marquant a áté l'absence presque totale de précipitations dès la mi-novembre jusqu'à la fin février, surtout dans le nord-est et le sud du pays $(16 \mathrm{~mm}$ de pluie à Bragança, alors qu'on enregistre, en moyenne, $400 \mathrm{~mm}$ durant cette période; $10 \mathrm{~mm}$ à Beja, aụ lieu de $250 \mathrm{~mm}$ ). Cette faiblesse des précipitations pendant la période normalement la plus arrosée de l'année fut la conséquence de l'installation persistante d'une dorsale dans l'Atlantique oriental, laissant sous abri aérologique une grande part de la Péninsule Ibéríque (fig. 5) Entre le 13 novembre et le 29 février, on compte ainsi 98 jours anticycloniques (tableau J). Ces anticyclones ont été variés par leur structure massique et leur position par rapport à la marge atlantique de la Péninsule, amenant tantôt des vagues de froid intense, sèches ou humides, tantôt des périodes plus douces, plus ou moins nébuleuses, parfois accompagnées de précipitations dans le nord-ouest du pays. On a distingué huit types principaux de situations anticycloniques (fig. 6 à 9), quui: se sont enchaînés en séquences plus ou moins durables. Les fluctuations des types de temps et la diversité géographique locale, très nette dans cette atmosphère particulièrement stable, ont été mises en rapport avec les structures massiques des anticyclones, notamment l'origine de la masse d'air inféIieure, et la hauteur et l'intensité de l'inversion thermique (fig. 10 à 12).

Les conséquences de la sécheresse le l'hiver 1980-81 ont été aggravées par un été particulièrement chand et sec et par la médiocrité des précipi-

(14) Ver H. H. LaMB, "Les fluctuations climatiques à long termes, La Météorologie, VI, n. ${ }^{\circ} 7$, Paris, 1976 
tations dès la mi-octobre jusqu'au début de décembre 1981. En novembre, qui est habituellement un des mois les plus arrosés de l'année, les pluies furent pratiquement nulles du nord au sud du pays. Cette situation a été due fondamentalement à l'installation d'un anticyclone ibéro-africain (tableau $V$ ), lié à une dorsale planétaire accentuée. qui a dirigé sur le Portugal un flux chaud et sec. Le rythme normal des pluies a repris la deuxième semaine de décembre, en mettant fin à une situation exceptionnelle qui durait depuis un an. On se demande si l'alternance récente d'années sèches (1974-75, 1975-76, 1980-81) et d'années très humides (1976-77, 1977-78, 1978-79) n'est pas le fait d'une accentuation de la circulation méridienne, aboutissant à des blocages plus fréquents et persistants dans l'Atlantique oriental et le sud-ouest de l'Europe.

\section{SUMMARY}

The 1980-81 trought in Portugal. Meteorological causes and types of weather. The hydrological year of 1980-81 was one of the driest in Portugal since meteorological records were first started, with serious consequences for agriculture, animal breeding and production of electricity. The evolution of rainfall and of the water balance in certain stations, chosen so as to afford a view. of regional variances, makes it possible to follow the unusual nature of the phenomenon (fig. 1 to 4 ). The most prominent feature was the almost total lack of rainfall from mid-November to the end of February, especially in the north-east and south of the country $(16 \mathrm{~mm}$ rainfall in Bragança, when the average for this period is $400 \mathrm{~mm} ; 10 \mathrm{~mm}$ in Beja, instead of $250 \mathrm{~mm}$ ). Such limited crainfall at the time of year when rainfall is usually most abundant, occurred as a result of the persistence of a ridge in the Eastern Atlantic. which left a large part of the Iberian Peninsula under an aerological helier (fig. 5). Thus, between 13th November and 28th February there were 98 anticyclonic days (table 1). These anticyclones were very varied as regards mass structure and position with respect to the Atlantic coast of the Peninsula. This at times caused intensely cold, dry or humid weather and at other times brought milder, more or less cloudy weather, sometimes with some rainfall in the north-west of the country. Eight main types of anticyclonic situation were observed (fig 6 to 9) which followed one after the other in a more or less durable sequence. The fluctuation "in weather types and local geographical diversity, very clear-cut in this particularly stable atmosphere, were related to the mass structures of the anticyclones, especially the source of the lower air mass and the height and intensity of the temperature inversion (fig. 10 to 12 ).

The consequences of the drought that occurred in the winter of 1980-81 were further heightened by an uncommonly hot and dry summer and by weak rainfall from mid-October through to the beginning of December 1981. In November, isually one of the wettest months of the year, there was practically no rain from north to south of the country. Essentially, this situation came about as a result of the presence of an Ibero-African anticyclone (table $V$ ), allied to a pronounced ridge wich sent a warm, dry airflow cwer Portugal. Normal rainfall rhythms returned in the second week of December. ending an exceptional situation which had lasted for a year. The writers pose a question: is the recent alternating of dry years (1974-75, 1975-76, 1980-81) and very wet years $(1976-77,1977-78,1978-79)$ not due to an increasing meridional circulation resulting in a greater recurrence and persistence of blocking in the eastern Atlantic and south-west Europe? 